\title{
You Only Die Once: Calvinist Dying and the Senses in Lille and Tournai During the Dutch Revolt
}

\section{LOUISE DESCHRYVER}

Louise Deschryver is a PhD student funded by the Research Foundation Flanders (Fwo) at the Department of Early Modern History of KU Leuven. Having investigated children's historical mentalities and emotions in modern times, she is currently working on a dissertation examining the close relationship between the death, the senses, and religious coexistence during the Dutch Revolt.

\begin{abstract}
Many historical studies have been published on how Lutheran and Calvinist teachings about death, salvation, and the Last Judgement differed from Catholic tradition. However, historians of the Reformation and death have not yet fully addressed how these diverging dying paradigms affected sensory practices of dying and burying among the laity. This article introduces attention to the senses in Catholic and Calvinist death rituals in the sixteenth-century Low Countries. It argues that how to use the body and the senses was at the heart of a chilling choice on which confessional death to die. By studying Catholic and Calvinist death rituals in sixteenth-century Lille and Tournai French-speaking frontier cities close to hotbeds of Calvinism - this article contributes to our understanding of sensory community and identity formation on a local level during the Reformation.
\end{abstract}

Keywords: death, Dutch Revolt, Reformation, senses

DOI 10.18352/emlc.127 - URL: http://www.emlc-journal.org

Publisher: Stichting EMLC, supported by Utrecht University Library Open Access Journals | The Netherlands Copyright: The Author(s). This work is licensed under a Creative Commons Attribution-NonCommercial 4.0 International License. 


\section{You Only Die Once: Calvinist Dying and the Senses in Lille and Tournai During the Dutch Revolt}

\section{LOUISE DeschryVER}

On 31 July 1566, the inhabitants of Tournai were confronted with an unusual spectacle. In his chronicle, the city's procureur-fiscal Pasquier de le Barre recounts how on this day a young woman was publicly buried by her parents and friends in the parish graveyard of Saint-Brice 'following the rules of the Genevan Church'. To this he added that 'the burial transpired without chime- or bell-ringing, without lights or accompanying clergy, holy water or any kind of chantries, which had until then been unseen in Tournai'. ${ }^{1}$ De le Barre's explicit and elaborate description of all the objects absent from the funeral procession suggests that Calvinist death rituals had - indeed - not only never before been seen in the city's daily life, but until then had also been quite unimaginable. His narrative mirrors the way in which this funeral procession struck him and its other witnesses, as he writes about the sensory rituals and liturgical objects that were conspicuous in their absence.

Many historical studies have been published on how Lutheran and Calvinist teachings about death, salvation, and the Last Judgement differed from those of Catholic tradition, and how this was cause for great strife between confessions. ${ }^{2}$ Nevertheless, cultural historians of death in the Reformation are yet to specifically address how knowledge of diverging Catholic and Protestant dying paradigms affected the sensory death practices of the early modern laity - and so are historians of the senses in the Reformation. Since Matthew Milner argued in his 2011 work The Senses and the English Reformation that the Reformation was in fact an empirical event, one centred around the question of how the senses could be used properly in religious devotion, studies on sensory community formation in the Reformation have abounded. ${ }^{3}$ Philip Hahn and Jacob Baum, for example, have recently conducted important work on how the hearing of bell-ringing and the smelling of incense

1 De le Barre and Soldoyer, Mémoires de Pasquier de le Barre, I, 117.

2 See for example Gordon and Marshall (ed.), The Place of the Dead; Koslofsky, The Reformation of the Dead; Reinis, Reforming the Art of Dying; Laqueur, The Work of the Dead; Lahtinen and Korpiola, Dying Prepared.

3 Milner, The Senses and the English Reformation, 1-12 and Milner, 'The Senses in Religion', 87-105. Just a few examples of recent studies on the senses in the early modern period and Reformation are MacDonald, Murhpy and Swann (eds.), Sensing the Sacred in Medieval and Early Modern Culture, 2018; De Boer and Göttler (eds.), Religion and the Senses in Early Modern Europe, 2013; Roodenburg (ed.), A Cultural History of the Senses in the Renaissance, 2014. 
respectively shaped confessional identity in the Holy Roman Empire. Attention to confessional dissension on the use of the senses in death and funeral rituals, however, has been scarce. ${ }^{4}$ This article will argue that the use of the body and the senses was at the heart of the chilling choice on which confessional death to die, affecting lay practices of dying and burying across the confessional spectrum.

The emergence of divergent theologies of death that accompanied the Reformation led to all the sensory elements of late medieval death rituals to be questioned. In pre-modern times, dying well required multiple sensory rituals and sacred objects upon which the fate of the soul depended. With the arrival of the Reformation, confessions argued between themselves about which sensory ars moriendi rituals constituted 'a good death' and which were superstitious. ${ }^{5}$ Should there be burning candles at the deathbed and in the funeral procession? Should the parish priest administer extreme unction? Should the church bells be rung or not? Should the grave be sprinkled with holy water and scented with incense - or would all of this be sinful idolatry? Answering these questions became of defining importance for the salvation of the soul of the deceased as well as of those attending the deathbed and funeral. After all, one could only die once, and it had to be done right. In this way, death rituals might just have become a site for the formation of confessionally shaped sensory repertoires par excellence.

In recent historiography, attention to death in the sixteenth- and seventeenth-century Low Countries has been limited to contributions by Andrew Spicer, Judith Pollmann, and Tiffany Bousard. Both Spicer and Bousard built upon the concept of sacred space in investigating burial disputes in sixteenth-century Bruges and Antwerp and the Dutch Republic respectively. Pollmann, on the other hand, showed how Catholics' emotional attachment to the Church as burial site of lost loved ones caused them to remain resentful of their loss of sacred space in the Dutch Republic. Building upon these insightful investigations, this article introduces attention to sensory repertoires of dying and burying into this research field in order to enhance and nuance our knowledge of the spatial and emotional dynamics of dying and burying on a local level in the early modern Low Countries. $^{6}$

Drawing upon chronicles, ars moriendi manuals, Calvinist instruction literature, martyrologies, city ordinances, and archival sources, this article studies Calvinist sensory rituals of death in sixteenth-century Lille and Tournai, which in spite of the limited geographical distance between them experienced the politico-religious turmoil of the Revolt in highly diverging ways. ${ }^{7}$ Although most of Tournai's early modern municipal archives were destroyed during a fire in World War II, this lacuna in source material will be countered by De le Barre's and Nicolas Soldoyer's chronicles, the diary of city alderman Philippe de

4 Baum, 'From Incense to Idolatry', 323-344; Hahn, 'The reformation of the soundscape', 525-545; Hahn, 'Lutheran sensory culture in context', 90-113.

5 Chartier, 'Les arts de mourir', 189-214; Selderhuis, 'Ars Moriendi in Early Modern Calvinism', 109-122; Reinis, Reforming the Art of Dying, 2007; Resch, 'Reforming Late Medieval ars moriendi', 153-172.

6 Spicer, 'Rest of their bones', 167-183; Pollmann, 'Burying the dead, reliving the past', 84-102; Bousard, 'Aan de rand van het graf, 59-86; Bousard, 'Rust in vrede?', 101-118.

7 Junot and Soen, 'La révolte des Pays-Bas habsbourgeois', 205 and 222. 
Hurges, and the early twentieth-century publications of Adolphe Hocquet, publications based on the sources which today are lost. ${ }^{8}$

Located in the north of present-day France and the southwest of present-day Belgium respectively, in the sixteenth century the French-speaking cities Lille and Tournai were closely situated to the southernmost border of the Habsburg Netherlands. Both were fairly large cities, with Lille housing about thirty thousand inhabitants, Tournai around twenty thousand. ${ }^{9}$ From the 1520 s onwards, both towns witnessed a swift growth of sympathy to Reformed ideas, which from the 1560 s were being spread during hedge sermons in the region's countryside. ${ }^{10}$ The proximity to the border with France emboldened Lutheran and Calvinist clergymen to preach Reformed beliefs more publicly than anywhere else in the Low Countries while they remained ready to flee to the safety of France at any time. ${ }^{11}$ Both cities' growing Calvinist communities were closely intertwined, partly because of the high mobility of Reformed ministers such as Pierre Brully and Guy de Brès, who were active in both towns. The latter was the author of the renowned Confession de Foy, the first codified Calvinist confession of faith in the Low Countries. ${ }^{12}$

The first section of this article charts the Calvinist rejection of late medieval sensory death repertoires in print, and the spreading of knowledge thereof among the laity of Lille and Tournai. The second section assesses sensory dying behaviours in Calvinist martyrologies, and investigates how the cities' most radical Reformed brought the emerging Calvinist sensory death repertoires into practice on the scaffold. A third section gauges the possibilities for moderate Calvinist believers to practice Calvinist dying on their deathbeds in the shifting politico-religious constellations created by the Dutch Revolt. The article concludes with a section on the end of the sixteenth and early seventeenth centuries, when Tridentine Catholicism was unevenly restored in both cities while Calvinist dying practices lingered in their urban communities.

\section{Calvinism and the Emergence of an Alternative Sensory Ars Moriendi}

In sixteenth-century Lille and Tournai, as in other early modern communities, death loomed large in daily life. ${ }^{13}$ While the dangers inherent in plague, war, and religious unrest threatened populations, the lives of individuals were put at risk on a daily basis by such commonplaces as infections or childbirth. ${ }^{14}$ At every burial, Lille's clergy reminded attendees of the inescapability of death and the need of lifelong preparation, stressing 'the

8 Verriest, 'La perte des archives', 186-193.

9 Morsa, 'L'urbanisation de la Belgique (1500-1800)', 329; Lottin, Lille, citadelle de la Contre-Réforme, 25.

10 Moreau, Histoire du Protestantisme à Tournai, 206-215; DuPlessis, Lille in the Dutch Revolt, 177 and 182; Deyon and Lottin, Les Casseurs de l'été 1566, 25-31.

11 Soen and Hollevoet, 'Le Borromée des anciens Pays-Bas?', 45; Junot and Soen, 'La révolte des Pays-Bas habsbourgeois', 207; Crew, Calvinist Preaching, 140-181.

12 Moreau, Histoire du protestantisme à Tournai, 91-10o and 136-140; Braekman, Guy de Brès, 42 and 65; Marnef, 'De Nederlandse Geloofsbelijdenis in context', 250-251.

13 Karant-Nunn, The Reformation of Ritual, 134.

14 Spinks and Zika (ed.), Disaster, Death and the Emotions. 
absolute certainty of death, and the absolute uncertainty of its hour' - a message likewise appearing in almost every testament made up in the region. ${ }^{15}$ In pre-modern societies, as Susan Karant-Nunn has aptly pointed out, keeping death in mind and preparing for it was a sensible rather than a morbid occupation.

In this vein, from the fifteenth century onwards, a new genre of religious books spread across western Europe. So-called ars moriendi manuals informed lay believers of the 'art of dying' and the behaviour and sensory rituals required to die a good death. In this late medieval tradition sensorial aids were considered helpful tools to guide the moribund through the final moment of life, when the faculties of the five senses were dwindling and the Devil was ready to attack the dying while they drew their very last breaths. ${ }^{16}$ Fixing one's gaze upon the crucifix (which was often life size), images of the Virgin or the Saints, and the aforementioned ars moriendi woodcuts were believed to have a consoling and protecting influence. ${ }^{17}$ If they wanted, the dying could also hold on to a crucifix themselves, press it against their chest, or kiss it. ${ }^{18}$ The attending priest, meanwhile, read biblical passages and prayers to the dying, so he or she could hear God's Word through his voice. ${ }^{19}$ Furthermore, the body was touched by the sprinkling of holy water, the burning taper that was put in their hands and in the anointing of the body with holy oil on the eyes, ears, nostrils, mouth, hands, and feet. The smell of burning incense, meanwhile, filled the death chamber, obscuring any potentially disagreeable odours that might be emitted by the sick body. ${ }^{20}$

For centuries, these sensory rituals had been considered to be protecting the dead body in a real and physical way, channelling salutary powers onto the body by touching it or just by being within its proximity. ${ }^{21}$ The senses, after all, could not only channel divine grace into the body, but were also the avenues through which sin was committed and evil forces were believed to enter it - even after (recent) death. ${ }^{22}$ So, in medieval and early modern times, those men and women who could afford it paid good money for the incorporation of burning torches, crucifixes, Latin chantries, holy water, and burning incense in their funeral service, as well as a good burial spot in holy ground, preferably in the church rather than the churchyard, and as close to the high altar as possible. ${ }^{23} \mathrm{~A}$ case in point were the funerals of the Low Countries' most powerful nobles. As we can read in the writings of a sixteenth-century Lillois nobleman, Guillaume Rugher, the lavish funerals of local nobility presented the sensory repertoires of the ideal Catholic funeral to the cities' inhabitants in splendid fashion. The sight, sounds, and smells of

15 Lottin, Lille, citadelle de la Contre-Réforme, 393.

16 Delumeau, Le Péché et la peur, 70-71.

17 Karant-Nunn, The Reformation of Feeling, 190; Chartier, 'Les arts de mourir', 52-53; Loart, La consolation des affligez, 516.

18 Resch, 'Reforming Late Medieval ars moriendi', 168.

19 Karant-Nunn, The Reformation of Feeling, 133; Loart, La consolation des affligez, 489-490, 516-517.

20 Karant-Nunn, The Reformation of Feeling, 135-136; Binksi, Medieval Death, 30-50.

21 Woolgar, 'What makes things Holy?', 61.

22 Roodenburg, 'Introduction', p. 10-14; Woolgar, 'What makes things holy', 60-78.

23 Bitter, Bonenkampová and Goudriaan (eds.), Graven Spreken, 42-50; Maillard-Luypaert, 'Pour le salut de mon âme', 7-51. 
these rare and exceptionally rich funeral ceremonies are sure to have made a lasting impression on the citizenry: funeral processions had hundreds of lighted torches, the church decorated with black draperies and coats of arms of noble families, all adding to the sensation of the warmth of hundreds of candles burning on the so-called chapelle ardente around the coffin..$^{24}$

Knowledge of Calvinist rejection of these sensory dying traditions reached Lille and Tournai soon after the onset of the Reformation. Numerous suspect books travelled along the trade routes connecting the commercial hearts of both cities with Antwerp, Geneva, Frankfurt, Heidelberg, Paris, and Lyon, and had already entered their city walls by the $1520 .{ }^{25}$ Reformed reading materials continued circulating in the following decades, despite the city magistrate's attempts to suppress the diffusion of heretical ideas ${ }^{26}$ As a large-scale book raid ordered by the Duke of Alba in 1569 revealed, one of the most widely read Calvinist authors in the French-speaking parts of the Low Countries - apart from Calvin himself - was Pierre Viret. ${ }^{27}$ He was one of Calvin's personal friends and the most important Reformed minister in Lyon in the $1560{ }^{28}{ }^{28}$ In his work L'office des Morts (1552), the Swiss Reformer lampooned the sensory death practices of the traditional Church as remnants of heathen rituals rather than of the old apostolic Church. Bell-ringing was only appropriate to remind the living of their own mortality, he argued, not to drive off demons nor to act as a call to prayer for the soul of the deceased. ${ }^{29}$ In fact, no sensory ritual whatsoever could influence the fate of the soul of the deceased anymore, not the fire of lighted torches nor the sound of singing voices. ${ }^{30}$ The smell of incense and the aromatic oil of the ritual of extreme unction, which in late medieval tradition was understood to be purifying and connecting the moribund to the sacred, Viret considered to be obsolete, as was sprinkling the body with holy water. ${ }^{31}$ Rather than engaging in these idolatrous practices, Viret wrote that true Christians should bury their dead without mourning sounds or objects, and without 'too much ceremony'. ${ }^{32}$ If the deceased had been baptised and the Holy Word was being preached, the funeral ceremony and burial site would be safe from demons. ${ }^{33}$ Similar ideas on Calvinist dying can be found in Le Baston de la Foy Chrestienne (1565), written by Guy de Brès, which he dedicated to the members of the Reformed church in

24 Lille, Bibliothèque Municipale Jean Lévy (hereafter BмL), ms 627, fol. 47-50, 253-255, 295-298, 320-323.

25 Marnef, Antwerpen in de tijd van de Reformatie, 65-75; Moreau, Histoire du protestantisme, 164-166; Afonso, Imprimeurs, société et réseaux, 15-21; DuPlessis, Lille and the Dutch Revolt, 170-171; Braekman, Guy de Brès, 64-66.

26 McDonald, 'Burned to Dust', 30-33.

27 Afonso, Imprimeurs, société et réseaux, 16-17; Moreau, 'Catalogue des livres brûlés à Tournai',194-213. For recent scholarship on the Council of Troubles and the Dutch book trade, see Adam, 'Men and books under watch', 301-321 and Adam, 'Édition', Orbi: Open Repository and Bibliography, http://hdl.handle.net/2268/230540 (Accessed on 17 July 2019).

28 Zemon Davis, 'The sacred and the body social', 49.

29 Viret, L'office des Morts, 74-75.

30 Viret, L'office des Morts, 27-47.

31 Viret, L'office des Morts, 75, Baum 'From Incense to Idolatry', 323-330.

32 Viret, L'office des Morts, 27.

33 Viret, L'office des Morts, 75. 
Lille and circulated in Tournai at the time of Alba's book raid in $1569 .{ }^{34}$ De Brès doubtless proclaimed these ideas during his time as minister in Tournai and Lille between 1552 and 1562.35

As a Reformed believer, it was not only the inclusion of idolatrous sensory practices in funerals that was to be avoided. Attending any kind of Catholic death ritual in general was considered detrimental, too. Since the 1540s, Calvin had been fulminating against Reformed believers partaking in Catholic sacramental rites in numerous publications, such as his Petit traité (1543), of which hundreds of copies circulated in Lille and at least some in Tournai. ${ }^{36} \mathrm{He}$ coined the term 'Nicodemite', after the biblical figure of Nicodemus, who did not wish to be seen with Jesus, but secretly visited him at night. Viret, too, in his Traittez Divers (1559) - which we know circulated in Tournai in the 1560 s - stated that members of the Reformed Church should not be getting themselves mixed up with Catholic funerals or commemoration masses. ${ }^{37} \mathrm{He}$ explicitly rejected the idea of attending these rituals as a form of neighbourliness or public civility, as it was more important to follow the example of Christ than to please man. ${ }^{38}$

Four years later, the Walloon synods of 1563 (presumably held in Antwerp) would approve the stance taken by Calvin and Viret on the attendance of Catholic funeral rituals. The synodal acts rather scantly stated that members of the Reformed Church were only allowed to attend a burial if no idolatry whatsoever was being practiced during the funeral. Certainly, Viret's writings gave the Reformed of both Lille and Tournai an opportunity to read which sensory death practices constituted idolatry. Still, just like the synodal acts, his L'office des Morts is much more informative on how Calvinist believers should no longer see, hear, smell, and feel death rituals, than on how they should sense them in the future. ${ }^{39} \mathrm{~A}$ straightforward answer to the question of what constituted a proper sensory attitude during Reformed burials was yet to be formulated and the theology of predestination made the writing of Calvinist ars moriendi literature anything but pressing..$^{40}$ In Calvinism, dying a good death became a sign of salvation, not a prerequisite for it. But if the final moments on the deathbed no longer were as decisive a moment for the salvation of the soul as in late medieval Catholic tradition, why write about it at all? As Milner has argued, the Protestant early modern laity 'adapted to the new religion by means of the old', so it is likely that members of the Lille's and Tournai's Reformed communities were still preoccupied with how to use their bodies on the deathbed in order not to risk eternal damnation..$^{41}$ For them, another source of information on Calvinist sensory dying practices, I will argue, were Calvinist martyrologies.

34 De Brès, Le baston de la foy chrestienne, 474-492; Braekman, Guy de Brès, 48; Moreau, 'Catalogue des livres brûlés à Tournai', 194-213.

35 Braekman, Guy de Brès, 45-85.

36 Turchetti, Tyrannie et tyrannicide, 374-417; Eire, War against the Idols, 234-275; Woo, 'The House of God in Exile', 222-244; Willens-Closset, 'Le protestantisme à Lille', 201-202; Moreau, 'Catalogue des livres brûlés à Tournai', 194-213.

37 Moreau, 'Catalogue des livres brûlés à Tournai', 194-213.

38 Viret, Traittez Divers, 132-134.

39 Moreau, 'Catalogue des livres brûlés à Tournai',194-213; Moreau, Les Synodes des Eglises Wallonnes, 8-11.

40 Chaunu, La mort à Paris, 253-254.

41 Milner, The Senses and the English Reformation, 9. 


\section{Exemplary Calvinist Dying on the Scaffold}

In sixteenth-century Lille and Tournai, the Livre des Martyrs, written in 1554 by Jean Crespin, was by far the most well-known and widespread martyrology.42 The book circulated widely in Walloon Flanders soon after publication. It was read aloud by Protestants during secret congregations and was found multiple times over in the bags of book pedlars travelling between the towns of Hainaut, Flanders, and Tournaisis. ${ }^{43}$ The Livre des Martyrs is imbued with stories of martyrs reforming or simply rejecting late medieval visual, aural, olfactory, and tactile death experiences. Readers of the martyrology - or those listening to it being read aloud - learned of French and Dutch martyrs actively turning their back on the statues of saints, calling them 'wooden idols', or refusing to gaze at crucifixes but instead looking firmly at the sky. They heard about men and women calling sacred oil a 'heathen relic of Judaism' and claiming the only thing one should feel is 'the oil of the Word of God' within. They read of how these martyrs would loudly sing the psalms of David in prison, on their way to the scaffold and while tied to the stake - sometimes with Catholic clergy trying to drown them out by singing Catholic hymns such as the Salve Regina and OSalutaris Hostia. ${ }^{44}$ In this way, martyr stories from cities all over the southern Low Countries and France enhanced the gradual development of a distinctive Reformed ars moriendi. Knowledge of Calvinist martyrs' alleged sensory attitudes in death spread with every copy of Crespin that secretly entered Lille and Tournai.

As these cities' Calvinist communities grew throughout the first half of the sixteenth century, some of their most radical members would put these printed ideas into practice on the scaffold themselves. Already in the 1520 Lille's and Tournai's city magistrates had 'members of the Lutheran sect' executed under the instruction of Charles $\mathrm{v}$ and after an inquisition of the faith by the bishop of Tournai. ${ }^{45}$ The following decades, the joint attempts of the secular and clerical authorities to eradicate growing sympathies to the Reformed cause resulted in regular public executions taking place on the cities' central markets. ${ }^{46}$ Through executions alone, forty-four inhabitants lost their lives in Lille between 1533 and 1564 .

Prison minutes as well as contemporary chroniclers tell us that many of these men and women died 'obstinately', sticking to their renunciation of the existence of purgatory even when already convicted to be burnt at the stake. ${ }^{47}$ In June 1561 , for example, in the case

42 For a recent publication on Jean Crespin, see Tucker, The Construction of Reformed Identity.

43 Gregory, Salvation at Stake, 190; Marnef, Antwerpen in de tijd van de Reformatie, 72-73.

44 Crespin, Recueil, 109, 128, 171, 227, 244-245, 252, 310, 314, 319-321, 344; Crespin, Actes des Martyrs, 142, 238-239, 906, 1067-1068, 1070, 1084.

45 BML, Ms 89, 2; Manteau and Chavatte, Chronique de Mahieu Manteau, I, 22, 33; Lottin, La révolte des Gueux, 26-27; Braekman, Guy de Brès, 65.

46 Manteau and Chavatte, Chronique de Mahieu Manteau, passim; Crespin, Actes des martyrs, 812-813; DuPlessis, Lille and the Dutch Revolt, 179.

47 Paillard, 'Le procès de Pierre Brully', 85-88; Moreau, Histoire du protestantisme à Tournai, 243; BML, MS 89, 1v; Manteau and Chavatte, Chronique de Mahieu Manteau, 28-29, 32, 51; Payen, Mémoires de Pontus Payen, 172; De le Barre and Soldoyer, Mémoires de Pasquier de le Barre, I, 46-47, 282; Crespin, Recueil, 226, 250; Crespin, Actes des Martyrs, 112, 227-239, 316-326, 502- 504, 722-724, 812-820, 995-1003, 1009-1013, 1023-1074, 1075-1084. 
of a Lillois tailor called Siméon, he continued to preach his Reformed ideas on purgatory and prayers for the dead to his fellow prisoners as well as to the Franciscan friars that tried to convert him in his final hours. ${ }^{48}$ On the scaffolds in the cities' central squares, Calvinist convicts refused to recommend their spirit to the Virgin Mary, as ordered by the attending clergy, but loudly proclaimed Christ to be their only advocate and intercessor. ${ }^{49}$ Similarly, they told the crowds the blood of Christ was the only purgatory Christians needed to reach heaven and refused the commemoration masses offered them, claiming these would not influence the fate of their soul at all..$^{\circ}$

Most traces of information on the dying behaviour of Lille's and Tournai's condemned Reformed are to be found in Crespin's Actes des Martyrs itself, which describes multiple executions of Calvinists from both cities. Historians have long debated the factual accuracy of the accounts of executions given by sixteenth-century martyrologists. ${ }^{11}$ Many historians have called attention to the generic nature of martyrologies, claiming these were primarily aimed at reinforcing Protestant collective identities rather than spreading factual information. ${ }^{52}$ Others, however, like Emile Braekman and Emilie Murphy, tend to give credence to their words, stressing the social networks upon which martyrologists depended for eyewitness information. ${ }^{53}$ Braekman has shown how the Reformed minister Guy de Brès provided Crespin with eyewitness information for his accounts of Lillois executions. ${ }^{54}$ It is not unlikely that Crespin made use of first-hand information in the writing of his other accounts of executions in the region as well. Before settling in Geneva, he had been involved in Calvinist circles of Arras and been able to build a network of Reform-minded informants living in the French-speaking parts of the Low Countries, among which he counted de Brès. ${ }^{55}$

One illustrative example on appropriate Calvinist ways of seeing during the final moments of life is Crespin's extensive report of the execution of the Orguier family in Lille in $1555 .{ }^{56}$ Arrested for having organised assemblies preaching 'erroneous doctrine', both parents and their two sons were condemned to death at the stake. In preparing the father to go to the scaffold, Franciscan monks begged him to 'at least carry a crucifix, so the crowd would not mutter. It was, after all, only a piece of wood to him.' Hearing this, Orguier's eldest son Baudichon pulled the crucifix from his father's hands and promptly threw it over his shoulder, admonishing him not to die an idolater. 'The people should not be offended by us, because we do not want a Jesus made from wood,' he said. 'We

48 BML, MS 89, fol. 1v; Frossard, L'église sous la croix, 52.

49 Crespin, Actes des Martyrs, 326.

50 Crespin, Actes des Martyrs, 503, 1069-1071; Frossard, L'église sous la croix, 77.

51 See for example Halkin, 'Les martyrologes et la critique', 52-72; Kelley, 'Martyrs, Myths, and the Massacre', 1323-1342; Collinson, 'Truth and Legend', 31-55.

52 See for example Halkin, 'Les martyrologes et la critique', 52-72; Kelley, 'Martyrs, Myths, and the Massacre', 1323-1342; Collinson, 'Truth and Legend', 31-55.

53 Braekman, Guy de Brès, passim; Murphy, 'Musical self-fashioning', 411.

54 Braekman, Guy de Brès, 45-47.

55 Gilmont, Jean Crespin, 32-39.

56 There is some uncertainty on which year this execution took place, as Crespin probably confused its exact date. According to Willens-Closset, the year 1555 is most likely, see Braekman, Guy De Brès, 50. 
carry Jesus Christ, the living son of God, in our hearts and we feel the Holy Word written in the bottom or our hearts in golden letters. ${ }^{57}$ Eventually, when Baudichon reached the scaffold himself, he did not fix his gaze upon a crucifix, but looked to the sky and claimed to the crowds he could see the heavens full of angels opening up for him. He then uttered a confession of faith and sang psalm sixteen from the Calvinist psalter by Theodore Beza. Finally, he and his father recommended their spirits to Christ and died at the same time.

Accounts of the Orguiers' passing doubtless resounded through the city soon after. A few years later, a printed version of this story in a new edition of the Livre des Martyrs reminded Lille's inhabitants, as well as their coreligionists in Tournai, what they should remember from the final moments of Baudichon and his father. Crespin explicitly stated that this martyr story was meant to instruct the faithful on 'which ornaments all fathers, mothers, children, and families truly needed in faith' and which they should continue with until their final moments in this life. These ornaments were 'the fruits of knowledge of the true faith', not - as the story instructs - crucifixes. ${ }^{58}$

Apart from the convicts' refusal to engage with sacred objects, especially striking is the recurrent motif of their singing psalms from the Genevan psalter, both in prison and on the scaffold. With this, Tournai's and Lille's most radical Reformed took heed of Viret's suggestion to sing in the final moments of life rather than during funerals, for - as a certain Noël Tournemine declared before his execution in Lille in 1566 - at that moment prayers could still influence the salvation of the soul..$^{59}$ Though psalms had already been a part of late medieval Catholic liturgy, in Calvinist circles these gained a more prominent place in collective sensory practices: according to Calvin, singing the psalms of David in the vernacular was an excellent way to praise the Lord. The hymns and psalms that Lille's and Tournai's convicts sang most often - the Cantique de Siméon as well as psalms 16, 27, 34, and 137 - had been given new melodies by Calvin and his Genevan collaborators in $1542 .^{60}$ These would no doubt have sounded familiar to those onlookers who had attended Reformed gatherings, but unknown and strange to the ears of Catholic attendants. As Emilie Murphy has shown for Catholic martyrs in sixteenth- and seventeenth-century England, martyrs consciously built upon the example of fellow believers who preceded them on the scaffold. Just like Catholics, Calvinist martyrs from Lille and Tournai imitated their executed coreligionists through their singing and thus furthered a Calvinist consolatory musical repertoire that could be imitated in private devotion. ${ }^{61}$ The cities' attendant Catholic clergy tried to discredit these Reformed sounds in various ways, either through not allowing the convicts to sing, through interrupting them, or by calling their psalms 'evil errors' Inadvertently, the clergy's unease with Reformed tunes must have affirmed their confessional significance to Catholic as well as Reformed onlookers, heightening awareness of these songs' sensory powers. ${ }^{62}$

57 Crespin, Actes des Martyrs, 815 .

58 Crespin, Actes des Martyrs, 812.

59 Viret, L'office des Morts, 43-47; Frossard, L'église sous la croix, 77.

60 Forney, 'The Netherlands, 1520-1640', 253; Luth, 'Het Geneefse Psalter', 182-193.

61 Murphy, 'Musical self-fashioning', 410-429.

62 Crespin, Actes des Martyrs, 238, 503, 815, 1067-1068, 1070, 1084; Frossard, L'église sous la croix, 39-40, 77. 
Through these spectacular and unusual executions, Catholic onlookers were confronted with the existence of an alternative death ritual, one confidently showcased by people so sure of their religious beliefs they were willing to die a painful death for them. ${ }^{63}$ Reformed attendants, on the other hand, now experienced the Calvinist sensory dying repertoires they had been hearing and reading about practiced in the flesh by their fellow believers and townsmen. As Brad Gregory has argued, executions of Protestants were 'deeply polarizing events', for a brief moment bringing the often blurred boundaries between confessional communities into focus. ${ }^{64}$ One of the boundaries Protestant executions brought to a head, I have argued here, was the confessional dissonance over the use of the body and the senses in death.

Still, we need to bear in mind that the sensory dying repertoires of Calvinist convicts were not only developed in tandem with Calvinist death theology, but also within the specific public context of violent death and execution. How and to what extent, then, might these have influenced the dying behaviours of ordinary Reformed believers? If these laymen and -women were dying, did they actively refuse the administration of extreme unction and other 'superstitious' Catholic death rituals? Or did they simply accept the arrival of the Catholic parish priest, his acolytes and the parish grave digger, the latter carrying the crucifix, ready to perform Catholic ars moriendi rites? ${ }^{65}$

\section{Negotiating the Senses on the Deathbed and in the Graveyard}

Not all of Lille's and Tournai's Reform-minded were as convinced that 'the only true purgatory was the blood of Christ', as was so often confidently proclaimed by their fellow citizens in the Livre des Martyrs. ${ }^{66}$ This we can learn from the notes of Charles de Tisnacq, a royal commissioner given the task of helping local authorities uncover heretical networks in the southernmost Low Countries in 1544-1545. ${ }^{67}$ Of the thirteen prisoners from Tournai he questioned for having attended Reformed gatherings, seven answered they did not know whether purgatory existed, some declaring that they had had doubts and discussions on the subject. Only one explicitly stated he believed there was a purgatory in the way the Catholic Church taught, two denied its existence altogether. ${ }^{68}$ Of course, we have to keep in mind these prisoners might have toned down their Calvinist opinions, since confidently denying purgatory was a one-way ticket to the scaffold - as indeed it turned out to be for the latter two prisoners. Still, the majority of them not simply claiming purgatory existed is significant and suggests that in the 1540s, when Tournai's Eglise de la Palme was already of considerable size, doubt about the existence of purgatory was very much present.

63 Nicholls, 'The Theatre of Martyrdom', 50-53.

64 Gregroy, Salvation at Stake, 142.

65 Lille, Archives Departementales de Lille (hereafter ADNL) 16 G 1159.

66 Crespin, Actes des Martyrs 229, 320, 1064, 1080.

67 Frossard, L'église sous la croix, 12-48.

68 Paillard, 'Le procès de Pierre Brully', 85-88. 
Doubt about which Church held the road to eternal salvation is sure to have fostered similar uncertainty on whether certain sensory deathbed practices were idolatrous. Though it is much more difficult to ascertain if Calvinist convicts' more moderate fellow-believers also used their senses in a distinctly Calvinist manner while in the privacy of their own dying chambers, we know that the leaders of Lille's and Tournai's Calvinist communities searched for ways to bring Reformed sensory death repertoires into practice for them too. In Lille, according to Crespin, under the ministership of first Guy de Brès and latterly Jacques de Lo, the flourishing clandestine Calvinist community assisted and consoled its sick and dying. ${ }^{69}$ In Tournai, prior to 1565 several Calvinists were assisted in their final moments by a fellow believer, the textile merchant Jehan Demasure. He was arrested in September 1565 for having consoled several of the dying on their deathbeds - in the process 'making a mockery of the ceremonies of the Catholic Church', according to the letter the commissioners wrote to Margaret of Parma. ${ }^{70}$

As Martin Christ has recently pointed out, domestic devotional practices such as those of the dying chamber were more difficult to control for clerical authorities. ${ }^{71}$ The private context of the death-chamber provided Lille's and Tournai's Reformed laity some elbow room to quietly prepare themselves for death the way they wished to. Perhaps, then, some of these Reformed men and women were consoled both by the Catholic clergy and their Reformed coreligionists, such as Demasure. As Penny Roberts has suggested for sixteenth-century France, the Dutch Reformed might also have avoided priestly intervention through conveniently only calling for one when it was already too late, and thence claiming death had come too suddenly to act in time..$^{2}$

One man who, according to Crespin, in the winter of 1561 actively refused the administration of the Catholic last rites, was Rogier Du Mont, a textile worker from Tournai. Several times he turned away his parish priest, refusing either to confess or receive the host, claiming he did not need any of these rituals because he was already at peace and assured of his salvation. As it turned out, Du Mont was not quite ready to die, and reportedly started to deliver inspiring sermons to mesmerized young Reformed after his deathbed epiphany. By recounting Du Mont's blunt refusal to receive extreme unction, Crespin provided the readers of his martyrology with a vivid example of a man making a very public statement on usually relatively privately conducted last rites. According to Crespin, in doing so, Du Mont had impressed many of his fellow Calvinists in town. ${ }^{73}$ It would be a further two years before, in December 1563 , Tournai's city magistrate arrested and executed him for his pernicious influence on the city's youth. ${ }^{74}$

Perhaps not coincidently, the Du Mont case occurred only two months after hundreds of Tournai's Reformed inhabitants claimed the public soundscape by walking through the

69 DuPlessis, Lille and the Dutch Revolt, 176; Crespin, Actes des Martyrs, 812.

70 De le Barre and Soldoyer, Mémoires de Pasquier de le Barre, I, 7.

71 Christ, 'Between Domestic and Public', 82.

72 Roberts, 'Burial disputes in sixteenth-century France', 136-137.

73 For a recent contribution to historical research on blurring private and public spheres in the death chamber, see Christ, 'Leisentrit's Instructions for the sick and dying of Upper Lusatia', 82-106.

74 Crespin, Actes des Martyrs, 1083-1084. 
city and loudly singing the psalms of the Genevan psalter, halting at places of Catholic worship. ${ }^{75}$ In fact, sources for Lille and Tournai consistently show that throughout the second half of the sixteenth century, occurrences of public day-to-day Calvinist dying and burying only surfaced during those moments where Calvinist worship - legally or illegally - had gained ground in the public sphere. These religious dynamics in both cities were highly volatile and subject to the changing politico-religious constellations of the Dutch Revolt. For Tournai, following the incident with Du Mont the sources make no more mention of deviant dying until the summer of 1566, when massively attended hedge sermons strengthened the Calvinist community in the city. Thus, on 31 July, the funeral procession of the unnamed Calvinist woman mentioned at the start of this article was the first public display of Calvinist sensory dying and burying repertoires in Tournai. ${ }^{76}$ De le Barre reports that a few weeks later, on 14 August, the rich textile merchant Hercule Clément was also buried 'in the Huguebot fashion' in the graveyard of Saint-Marguerite. ${ }^{77}$

That these Calvinist families chose a traditional burial place for their deceased kin - even if they deemed the parish graveyard ground no longer holy in itself - is not as surprising as it may seem. As Spicer and Roberts have shown for Protestant believers in Scotland, France, and the northern Netherlands, early modern funerary rituals had a social as well as liturgical meaning, which was not as easily dismissed as Viret might have wished..$^{78}$ Indeed, even a Calvinist convict who was executed in 1566 in Tournai was afterwards buried in the parish graveyard of Saint-Quentin by some members of the Reformed Church. ${ }^{79}$ Nevertheless, attention to the sensory repertoires of these burials shows that while Calvinist families might have readily buried their dead in traditional graveyards, this did not necessarily mean they continued to adhere to traditional Catholic dying practices altogether. On the contrary, for these Tournai cases, the burial location seems to have been less a matter of confessional identity than the Calvinist sensory behaviours displayed to the urban community during the funeral procession. Roberts has made a similar observation for Huguenot burials in sixteenth-century France, finding French Protestants to be more concerned with the exclusion of Catholic rituals in their funeral services and processions than with finding a new, non-Catholic burial ground. The fact that De le Barre made no mention whatsoever of these Calvinist burials causing Catholic uproar in the city - as they often did across the border in France - is telling of the strength of the Calvinist community in Tournai on the eve of the Dutch Revolt. ${ }^{80}$

Barely ten days after the funeral of Hercule Clément, an iconoclast revolt struck the city. With the violent destruction of devotional objects in many churches across the Low Countries, Protestants aimed to erase traditional Catholic sensory practices of devotion. ${ }^{81}$ In the two towns under scrutiny here, however, the threat of iconoclasm resulted in highly

75 Moreau, Histoire du protestantisme, p. 167-191.

76 De le Barre and Soldoyer, Mémoires de Pasquier de le Barre, I, 117.

77 De le Barre and Soldoyer, Mémoires de Pasquier de le Barre, I, 131.

78 Spicer, 'Rest of their bones', 167-183; Roberts, 'Burial disputes in sixteenth-century France', 139-140.

79 De le Barre and Soldoyer, Mémoires de Pasquier de le Barre, I, 278.

8o Roberts, 'Burial disputes in sixteenth-century France', 140.

81 For a recent contribution to the historiography of the Iconoclastic Fury in the Low Countries see Van Bruaene, Jonckheere and Suykerbuyk (eds.), 'Beeldenstorm'. 
different outcomes. Where in Tournai iconoclasts ravaged parish churches, tombstones, and even citizens' homes, in Lille the mobilisation of a Catholic civic militia by governor Rassenghien prevented its Reformed inhabitants from entering the city's churches. ${ }^{82}$ Subsequently, when in the negotiations following the summer of 1566 Protestant communities were granted provisional rights of public worship by Governor Margaret of Parma, in Lille only previous hedge sermons were allowed to continue. In Tournai, on the other hand, in November 1566 the consistory asked Hornes, the city governor, for the permission to freely profess their faith, explicitly requesting, amongst other things, to be allowed to visit the sick and bury their dead according to 'the primitive Church of the Apostles' ${ }^{83}$ Hornes, interpreting the temporary agreements much more loosely than Rassenghien, conceded and gave permission to build an extra muros Protestant temple. ${ }^{84}$

The freedom of religion enjoyed by Tournai's Protestants was, however, short-lived, as by January 1567 it was brought back under the strict authority of the Crown and Catholicism was reinstalled as the city's official religion. ${ }^{85}$ With the arrival of the Duke of Alba and the installation of the Council of Troubles in September 1567, many citizens left their hometowns fearing prosecution. ${ }^{86}$ Calvinists remaining in Tournai no longer saw opportunities for publicly burying their dead 'in the Genevan fashion' and seemingly accustomed themselves to the new politico-religious status quo. Pasquier tells for example how in February 1567 a Calvinist couple who had lost their - equally Calvinist - son wished to have the bells rung for him 'along with all the other things necessary for the burial of a body' and to bury him in the graveyard of the Notre Dame cathedral. In accordance with social and sensory traditions, they wished for his death to be aurally announced to the community and his body to quite literally be incorporated in the local 'community of the dead'. ${ }^{87}$

However, if on the tense eve of the Iconoclastic Fury and during its confused aftermath Calvinists had been free to bury their dead in the local graveyards of Tournai, after the reinstallation of Catholicism this was no longer the case. The cathedral priest refused to bury the corpse of 'someone who had strayed from Catholic religion and had attended the sermons in their graveyard or any other'. The city magistrate, then, ordered the parents to bury their son in profane ground outside the city walls, preferably in the little garden outside one of the city gates where the bodies of executed criminals were buried.$^{88}$ Eventually the couple buried their son among the foundations of the Calvinist temple that had

82 Suykerbuyk, 'De sacra militia', 27. For more information on the role of the civic militia in nearby Valenciennes see Junot, 'Les milices bourgeoises', 35-46.

83 De le Barre and Soldoyer, Mémoires de Pasquier de le Barre, I, 237-238.

84 Junot and Soen, 'La révolte des Pays-Bas habsbourgeois', 208-211; Marnef, 'The Dynamics of Reformed Militancy', 51-58, 68 .

85 Soen, 'Collaborators and Parvenus?', 20-38.

86 Junot and Soen, 'La révolte des Pays-Bas habsbourgeois', 215; Rolland, Histoire de Tournai, 206.

87 Koslofsky, The Reformation of the Dead, 2; Laqueur, The Work of the Dead, 145-150.

88 In all likelihood, the place mentioned here is the 'Happart', a place outside the Saint-Martin city gate where Tournaisis criminals were executed - and presumably also buried. See Hurghes, Mémoires d'eschevin de Tournay, 129. In Lille criminals, heretics and witches were officially buried in the 'lieu de'eu', outside the city walls near the 'Porte des Malades' to the south of the city, see Lottin, Lille, citadelle de la Contre-Réforme, 399. 
been built and demolished again the year before. ${ }^{89}$ This way, they gave him a resting place with symbolic if not holy meaning, with his body marking him as a member of the local Calvinist community, if not the parish. Even in times of repression, Tournai's Calvinists found ways to adjust the symbolic social significance of death within the boundaries of their limited confessional freedom.

In spite of Alba's attempts at forcefully reinstalling Catholic sensory worship, sympathies with the Reformed cause continued to linger in both towns up to the second half of the sixteenth century. As opposed to the relatively peaceful religious status quo in Lille after 1566, in Tournai the appointment of Pierre de Melun as city governor by the States-General in 1576 gradually led to the installation of a Calvinist regime. The following years, Tournai's Calvinists once again baptised their children and married according to Protestant rituals, as well as openly burying their dead 'in hallowed grounds' (in all likelihood the traditional community graveyards), without passing through the Catholic Church. ${ }^{90}$ By October 1581, however, the Duke of Parma besieged the city. Tournai capitulated after one month and was brought back under the control of the Crown. ${ }^{91}$ According to the eyewitness account of the Catholic inhabitant of Tournai Philippe Warny, during the Parma's solemn entry on 1 December the city's Catholics joyfully sang the Te Deum Laudamus and walked behind the 'one true cross' that was carried to Parma by the cathedral's canons. ${ }^{92}$

In the second half of the sixteenth century, then, moderate Calvinist believers in Lille and Tournai seem to have negotiated the confessional confusion on appropriate sensory death practices rather pragmatically, within the ever-changing boundaries set for them by the ongoing Dutch Revolt. As Pollmann has shown, in the seventeenth century Catholics in the Dutch Republic dealt creatively and flexibly with limited possibilities to bury their dead according to Catholic traditions. So too did Reformed believers in sixteenth-century Lille and Tournai, taking parts of their repertoires of death (for example a silent funeral procession) and combining these with Catholic funerary traditions (allowing the presence of Catholic clergy at the deathbed, burying the body in holy ground). ${ }^{93}$ This way, they dealt with the fear of death and the uncertainty on sensory death rituals in a way deemed acceptable given their precarious religious position.

The importance of urban politico-religious contexts in defining the confessional funerary 'sensescape' of a city is illustrated here by the fact that all examples of overtly Calvinist day-to-day sensory dying practices mentioned originate from Tournai rather than Lille. As Tiffany Bousard has shown for Bruges and Antwerp, legislative actions undertaken by the state, bishops, and city magistrates deeply influenced the face of urban multi-confessional funerary landscapes. ${ }^{94}$ In Lille, sympathies to Reformed beliefs were - though certainly present - not as widespread as in Tournai. Furthermore, in Tournai the Reformed could

89 De le Barre and Soldoyer, Mémoires de Pasquier de le Barre, II, 67.

90 Hocquet, Tournai et le Tournaisis, 213-230.

91 Delplancq, 'Le retour de Tournai dans le giron espagnol', 99-151; Junot, 'Pratiques et limites', 327-346.

92 Delplancq, 'Le retour de Tournai dans le giron espagnol', 99-151; Warny de Wisenpière, Mémoires, 32-33.

93 Pollmann, 'Burying the dead; reliving the past', 84-102. For Catholic burying practices in the Dutch Republic see also Mudde, Rouwen in de Marge.

94 Bousard, 'Aan de rand van het graf', 59-86; Bousard, 'Rust in vrede?', 101-118. 
count on the support and protection from some notables and members of the city magistrate. ${ }^{95}$ In the case of the aforementioned Calvinist burial of Hercule Clément, for example, the city confiscated Clément's goods, including his five different houses. They did not, however, prosecute any of his family members, who doubtless attended the funeral. ${ }^{96}$ Though Lille's city magistrate regularly issued ordinances prohibiting its inhabitants to marry 'in the Genevan way' or to baptise their children during hedge sermons, the city legislation remains silent on matters of Protestant dying and burial practices. All three of these rituals were prohibited within the city walls, but whereas the former two could easily be performed on the countryside, doing the same for burial rituals was much less feasible. ${ }^{97}$ Thus, it seems Lille's Reformed inhabitants were generally forced to resort to Nicodemite strategies in matters of dying. ${ }^{98}$

\section{Deviant Dying at the Turn of the Seventeenth Century}

The arrival of Parma put an end to decades of religious uproar in Lille and Tournai, and led to the departure of reportedly thousands of Reformed believers to the Holy Roman Empire, the British Isles, and the northern Netherlands. ${ }^{99}$ While Calvinist presence in both cities was thus reduced significantly, from the 158 os onwards the secular and clerical authorities of both cities were quick to implement a Counter-Reformation program. With the growing circulation and production of Tridentine Catholic printings in the southernmost regions of the Low Countries, the reading laity of Lille and Tournai were flooded with books spreading the ideas and ideals of the Catholic Church. ${ }^{100}$ Instructing the laity on how to die a good Catholic death was an important element of this offensive, for remembering and contemplating death and the Last Judgement was deemed a great stimulus towards living a good Christian life. ${ }^{101}$

In order that they might maintain a daily emotional state of healthy anxiety, authors of Tridentine ars moriendi manuals encouraged their readers to appeal to their senses, as outward sensory stimuli were believed to directly influence the inner state of devotion. In La consolation des Affligez (1594), for example, the Jesuit Gaspar Loart recommended to place a skull in the middle of the house, to pay regular visits to local churchyards in order to see - and often smell - the graves and bones of the dead, to recite certain psalms, and to attend as many deathbed rituals as possible. All these rituals, he argued were helpful

95 Lottin, Lille, citadelle de la Contre-Réforme, 190; Moreau, Histoire du protestantisme à Tournai, 389; DuPlessis, Lille and the Dutch Revolt, 184.

96 Moreau, Histoire du Protestantisme à Tournai, 276.

97 Lille, Archives Municipales de Lille (hereafter AML), Fonds Desplanque, Registres des Ordonnances du Magistrat, cotes 381-388; AML, Fonds Desplanque, Registres aux Mandements du Gouvernance, cotes 16976-16984; AML, Fonds Desplanque, Registres dits aux résolutions du Magistrat, cotes 277-281.

98 Willens-Closset, 'Le protestantisme à Lille', 201-202; DuPlessis, Lille and the Dutch Revolt, 212.

99 Delplancq, 'Le retour de Tournai dans le giron espagnol', 132-151; Lottin, 'Le bannissement', 481-498.

100 Soetaert, De katholieke drukpers, 265-267.

101 Lottin, Lille, citadelle de la Contre-Réforme, 393; Louart, La Consolation des Affligez, 443-450. 
sensorial experiences to mould and practice the right kind of fear of death. ${ }^{102}$ Jean Huchon, the parish priest of Saint-Sauveur in Lille, reminded the clergy in his manual Le Flambeau des Chrestiens (1635) of the importance of administering Holy Oil to all the faculties of the five senses, as these were the channels through which the moribund had committed all his or her sins in this life. ${ }^{103}$ A similar message can be found in La Reine des Scieces, an ars moriendi manual written by Gilles de Vendeville, a Franciscan monk from the abbey of Loos near Lille. He specifically instructed Lille's laity to receive the unction on the eyes, the ears, the nostrils, the lips (or mouth), the hands, the feet, and finally the loins, while the administering cleric recited a prayer at the touch of every one of these body parts. De Vendeville also paid special attention to the salutary powers of burning perfumed torches and aromatic lamp oil in the death-chamber. Dying within these purifying scents would surely please God and the Angels, he wrote, for these mimicked the holy scents of heaven. De Vendeville thus reaffirmed the late medieval belief that sacred scents could connect the moribund with the hereafter - a belief Reformers had forcefully refuted. ${ }^{104}$

Still, both towns' inhabitants must have been aware that Calvinism was not only gaining ground in the northern parts of the Low Countries, but was also very much alive in nearby France, where the 1598 Edict of Nantes allowed Protestants to worship in public. ${ }^{105}$ Meanwhile, as Lille's and Tournai's textile workers migrated to and from industry centres in the Dutch Republic such as Leiden, some of them brought Reformed religious beliefs and habits back home. ${ }^{106}$ In the late sixteenth and early seventeenth centuries, men and women in both towns were regularly prosecuted for continuing to sell Protestant books, organising Calvinist assemblies, or damaging saints' statues and crucifixes. ${ }^{107}$

Similarly, Calvinist ways of dying lingered discreetly amidst the Catholic rites of daily life. When in 1610, according to Tournai's alderman Philippe de Hurghes, an innkeeper died of 'plague ridden with the poison of the damnable heresy of Calvin', the prosecutor started a rigorous investigation into the beliefs and mores of his child who wished to continue his father's business. ${ }^{108}$ In Lille, two chroniclers mention a dying man ostensibly rejecting Catholic dying practices in 1603. Antoine de Croix had died 'a heretic', after which the city magistrate ordered his body buried in profane ground outside the city walls. It was carried in a wheelbarrow to the garden of his father's house, where the man was buried near the river. The following Sunday, his grave was violated by 'doctors', who removed the organs from his body, embalmed the corpse, and buried his entrails 'deep in

102 Loart, La consolation des affligez, 442-482.

103 Huchon, Le Flambeau des Chrestiens, 376-377.

104 De Vendeville, La reine des Sciences, fol. 56-57 and 61v.-62.

105 Spicer, 'After Iconoclasm', 424-425; Lestringant, Le Théâtre des Cruautés, 8-9; Soetaert, De katholieke drukpers, 90-94.

106 Lucassen and De Vries, 'The Rise and Fall', 23-42; Junot, 'Heresy, War, Vagrancy', 61-80.

107 Frossard, L'église sous la croix, 126; BML, MS 89, fol. 20 and 25v.; AML, Fonds Desplanque, Registres aux Ordonnances du Magistrat, cote 381, 142; AML, Fonds Desplanque, Registres aux Ordonnances du Magistrat, cote 382, 85; AML, Fonds Desplanque, Registres aux Ordonnances du Magistrat, cote 384, 80v-84; AML, Fonds Desplanque, Registres aux Ordonnances du Magistrat, cote 385, 24 and 38v, AML, Fonds Desplanque, Registres aux Ordonnances du Magistrat, cote 386, 189; Lottin, Lille, citadelle de la Contre-Réforme, 197-200.

108 Hurghes, Mémoires d'eschevin de Tournay, 223-224. 
the ground'. ${ }^{109}$ News of this 'scandalous affair', as one of the chroniclers called it, spread through town, reminding Catholics once more of the hidden adherence to different dying rituals in town. According to the chronicle of Frossard, his death also inspired at least one of his fellow believers, the textile worker Jean Favorau. In September 1603, he was brought before Lille's city council after having repeatedly uttered 'heretic' beliefs and psalms to his fellow citizens - amongst other things rejecting the existence of purgatory and the use of prayers for the dead. There he declared Antoine de Croix had 'done very well' in refusing to confess and receive extreme unction, and that he would gladly die the same way. On his deathbed, he declared, he would turn away the parish clergy and would not care whether he was buried in sacred ground or beneath the gallows, because no ground was holier than the other. Though Favoreau was eventually banned from Lille for his blunt and brazen adherence to Calvinism, undoubtedly some of his more discreet fellow believers still resided in town, reminded of the confessional significance of the appropriate sensory repertoires on the deathbed. ${ }^{110}$

\section{Conclusion}

This article has argued that with the arrival of the Reformation not only theological teachings on death and the afterlife, but also sensory dying and burying practices became an element of confessional divergence and community formation. Confronted with the existence of multiple roads to eternal salvation in print as well as in daily life, members of early modern urban communities found themselves beset by the fundamental question of which Church was the true one, and which path to heaven to follow. After all, one could only die once - and it needed to be done right. How to use one's senses in preparing for death during life as well as on the deathbed, I have argued here, was at the heart of the confessional strife on death and dying. As such, death rituals can be considered a crystallisation point of sensory confessional community formation par excellence.

Attention to dissension on the use of the senses in death rituals and on the scaffold suggests that the iconoclast revolt and its aftermath was far from the first serious catalyst for sensory conflict in the sixteenth-century Low Countries, as scholarship sometimes seems to suggest. ${ }^{111}$ Sympathies to the Reformed cause were already growing in Lille and Tournai early in the sixteenth century. From the 1540 s onwards - a solid twenty years before the Iconoclastic Fury - Calvin's and Viret's ideas on Calvinist dying spread through the circulation of their printed instruction literature. From the 1550s, Crespin's famous Livre des Martyrs furthered the practical elaboration of their convictions. A considerable number of the cities' inhabitants brought these newly developing Reformed dying practices into practice on the scaffold before 1566. They also drew from existing examples of Reformed dying on the scaffold and as such contributed to their further elaboration and spreading.

109 Manteau and Chavatte, Chronique de Mahieu Manteau, 83-84; BML, MS 582, $176 \mathrm{v}$.

110 Frossard, L'église sous la croix, 138-140.

111 See for example Van Bruaene, Jonckheere and Suykerbuyk (eds.), 'Beeldenstorm'; Jonckheere, Antwerp Art After Iconoclasm; Spicer, 'After Iconoclasm', 411-433. 
For less radical members of the Reformed Churches of Lille and Tournai, the volatile political constellations of the Dutch Revolt would shape highly diverging opportunities to bring these ideas into sensory practice on the deathbed and during funerals. Lille's Reformed inhabitants found few opportunities to die and bury their dead in a solely Calvinist way and were forced to resort to Nicodemite strategies in coping with death. In Tournai, on the other hand, the public psalm-singing of 1561 possibly gave Du Mont the courage to openly reject the administration of extreme unction, while the massively attended hedge sermons in the summer of 1566 encouraged some families to bury their dead 'in the Genevan fashion', though in traditional burial grounds. The emergence of a Calvinist Republic in Tournai in the late 1570 s offered the city's Calvinists a fresh opportunity to perform Calvinist sensory repertoires of death, but eventually Tridentine Catholicism was reinstalled within its walls as it had been in Lille.

For the most part, it would seem Lille's and Tournai's Reformed population negotiated the multiple ways to salvation in a pragmatic way, within the boundaries of their confessional freedom. Although for both Lille and Tournai sources indicate that Calvinist assistance and rituals at the deathbed were being practiced, we find few cases in which the cities' inhabitants actively refused the administration of extreme unction by the parish clergy. On the other hand, even if some Calvinists allowed for the crucifix to be put before their eyes, the taper put in their hands, and extreme unction to be given them, we can be sure they realised the danger of becoming, in the words of Baudichon, 'an idolater in their final moments'. With the arrival of the Reformation, Catholics as well as Reformed realised that how they used their bodies and their senses on the deathbed was a matter of importance that could influence the eternal fate of their soul, as well as signify a confessional identity that would last beyond this life.

\section{Bibliography}

\section{Archival and Manuscript Sources}

Lille, Archives Départementales du Nord (ADNL), 16 G Chapitre Saint-Pierre de Lille, cote 1159, Lille. Paroisse Sainte-Marie-Madeleine. Petit personnel (xvire-XvinIe s.). Coutre, bailli, organiste, sonneurs, fosier, $17^{\text {th }}-18^{\text {th }}$ century.

Lille, Archives Municipales de Lille (AML), Fonds Desplanque, cotes 277-281, Registres dits aux résolutions du Magistrat, 1547-1653.

AML, Fonds Desplanque, cotes 381-386, Registres aux Ordonnances du Magistrat, 1551-1622.

AML, Fonds Desplanque, cotes 16980-16983, Registres aux Mandements de la Gouvernance, 1559-1657.

Lille, Bibliothèque Municipale Jean Lévy (вмL), MS 43, Méditations et prières, en flamand, 15 th century.

BML, MS 89, Bocquet. Bref description des choses plus remarqués, advenues tant en la ville de Lille q[u]'ailleurs, depuis l'an 1500 jusques [1694], 17th century.

BML, MS 110, Gilles de Vendeville, La Reine des Sciences ou le plus beau de tous les secrets qui nous apprend à bien mourir, 17 th century.

BML, MS 582, fol. 169-195, Journal de Monnoyer, 1592-1618.

BML, MS 627, Guillaume Rugher, Recoeul de plusieurs obsecques et pompe (sic) funèbres célébrées en diverses manières selon les ordonnances des officiers ad ce commis et coustumes des lieux, tant anchiennes que modernes, assemblées et extraictes de plusieurs histoires, registres et papiers autenticques de 
ce que j’ay peu avoir la cognoissance, par moy Guillame (sic) Rugher, hérault d’armes du pays et comté de Haynaut, ensemble de la ville et chastelleinie de Lille, lieu de ma résidence, 16th century.

BML, MS 678, Chronique Lilloise, 1600-1662.

\section{Printed Sources}

Adam, Renaud, 'Men and books under watch. The Brussels' book market in mid-sixteenth century through the inquisitorial archives', in Graheli Shanti (ed.), Buying and Selling. The Early Book Trade and the International Marketplace (Leiden 2019) 301-321.

Adam, Renaud, 'Édition de l'inventaire des livres trouvés chez les libraires montois le 16 mars 1569', Orbi. Open Repository and Bibliography, http://hdl.handle.net/2268/230540 (Accessed on 17 July 2019).

Afonso, Sébastien, Imprimeurs, société et réseaux dans les villes de langue romane des Pays-Bas méridionaux (1580-ca. 1677). PhD diss., Université libre de Bruxelles, 2016.

Baum, Jacob, 'From Incense to Idolatry. The Reformation of Olfaction in Late Medieval German Ritual', The Sixteenth Century Journal 44 (2013/2) 323-344.

Bousard, Tiffany, 'Aan de rand van het graf. De transformatie van het funeraire leven en landschap in Antwerpen en Brugge tijdens de calvinistische republieken (1577/1578-1584/1585)', in Liesbeth Geevers and Violet Soen (eds.), Sacrale ruimte ín de vroegmoderne Nederlanden (Leuven 2017) 59-86.

Bousard, Tiffany, 'Rust in vrede? Begrafenissen en religieuze controversen in Brugge tijdens de Nederlandse Opstand (1562-1584)', Handelingen van de Koninklijke Zuid-Nederlandse Maatschappij voor Taal- en Letterkunde en Geschiedenis 68 (2014) 101-118.

Braekman, Emile, Guy de Brès. Un réformateur en Belgique et dans le Nord de la France (1522-1567) (Mons 2014).

Binksi, Paul, Medieval Death. Ritual and Representation (London 1996).

Bitter, Peter, Viera Bonenkampová, and Koen Goudriaan (eds.), Graven Spreken. Perspectieven op grafcultuur in de middeleeuwse en vroegmoderne Nederlanden (Hiversum 2013).

Chartier, Roger, 'Les arts de mourir 1450-1600', Annales. Histoires, Sciences sociales 31 (1976/1) 51-75.

Chaunu, Pierre, La mort à Paris, $16^{\mathrm{e}}, 17^{\mathrm{e}}, 18^{\mathrm{e}}$ siècles (Paris 1978).

Christ, Martin, 'Between Domestic and Public. Johann Leisentrit's (1527-1586) Instructions for the Sick and Dying of Upper Lusatia, in Marco Faini and Allesia Meneghin (eds.), Domestic Devotions in the Early Modern World (Leiden 2019) 82-106.

Collinson, Patrick, 'Truth and Legend. The Veracity of John Foxe's Book of Martyrs', in Alistair Duke and Coen Tamse (eds.), Clio's mirror. Historiography in Britain and the Netherlands (Zuthpen 1983) 31-55.

Crespin, Jean, Actes des Martyrs deduits en sept livres depuis le temps de Wiclef et de Hus jusques à présent (Geneva 1565).

Crespin, Jean, Recueil de plusieurs personnes qui ont constamment enduré la mort (Geneva 1555).

De Boer, Wietse, and Christine Göttler (eds.), Religion and the Senses in Early Modern Europe (Leiden 2013).

De Brès, Guy, Le baston de la foy chrestienne propre pour rembarrer les ennemis de l'Evangile (Geneva: Thomas Courteau, 1565).

De le Barre, Pasquier, and Nicolas Soldoyer, Mémoires de Pasquier de le Barre et Nicolas Soldoyer pour servir à l'histoire de Tournai 1565-1570. Alexandre Pinchart (ed.), 2 vols. (Brussels 1859-1865).

Delplancq, Thierry, 'Le retour de Tournai dans le giron espagnol', Mémoires de la société royale d'histoire et d'archéologie de Tournai, 9 (1997) 99-151.

Delumeau, Jean, Le Péché et la Peur. La culpabilisation en Occident XIIIe-XVIIIe siècles (Paris 1983).

Deyon, Solange, and Alain Lottin, Les Casseurs de l'été 1566. L'iconoclasme dans le Nord de la France (Paris 1981).

DuPlessis, Robert, Lille in the Dutch Revolt. Urban Stability in an Era of Revolution 1500-1582 (Cambridge 1991). 
Eire, Carlos, War against the Idols. The Reformation of Worship from Erasmus to Calvin (Cambridge 1986).

Forney, Kristine, 'The Netherlands, 1520-1640', in James Haar (ed.), European Music 1520-1640 (Woodbridge 2006) 246-279.

Frossard, Charles-Louis, L'église sous la croix pendant la domination espagnole. Chronique de l'église réformée de Lille (Paris 1857).

Gilmont, Jean-François, Jean Crespin. Un éditeur réformé du xvıe siècle (Geneva 1981).

Gordon, Bruce, and Peter Marshall (eds.), The Place of the Dead. Death and Remembrance in Late Medieval and Early Modern Europe (Cambridge 2000).

Gregory, Brad, Salvation at Stake. Christian Martyrdom in Early Modern Europe (Cambridge 2001).

Giucciardini, Ludovico, Beschryvinghe van alle de Neder-landen anderssins ghenoemt Neder-Duytslandt, Cornelium Kilianum trans. (Amsterdam: Wimmel Jansz, 1612).

Hahn, Philip, 'Lutheran sensory culture in context', Past and Present Supplement 12 (2017) 90-113.

Hahn, Philip, 'The reformation of the soundscape. Bell-ringing in early modern Lutheran Germany', German History 33 (2015/4) 525-545.

Halkin, Leon, 'Les martyrologes et la critique. Contribution à létude du martyrologe protestant des PaysBas', in Mélanges historiques offerts à Monsieur Jean Meyhoffer (Lausanne 1952) 52-72.

Hocquet, Adolphe, Tournai et le Tournaisis au Xvie siècle, au point de vue politique et social (Brussels 1906). Huchon, Jehan, Le Flambeau des Chrestiens ou exposition des sept sacrements (Lille: Simon le Francq, 1635).

Hurges, Philippe de, Mémoires d'eschevin de Tournay par Philippe de Hurges 1609-1611. Frédérique Hennebert (ed.) (Tournai 1855).

Jonckheere, David, Antwerp Art After Iconoclasm. Experiments in Decorum 1566-1585 (New Haven 2012).

Junot, Yves, and Violet Soen, 'La révolte des Pays-Bas habsbourgeois. Reconsidérations à partir du cas des provinces francophones (Hainaut, Artois, Flandre wallonne, 1566-1579)', in Gregorio Salinero, Águeda García Garrido, and Radu Paun (eds.), Paradigmes rebelles. Pratiques et cultures de la désobéissance à l'époque moderne (Bern 2018) 203-224.

Junot, Yves, 'Heresy, War, Vagrancy and Labour Needs. Dealing with Temporary Migrants in the Textile Towns of Flanders, Artois and Hainaut in the Wake of the Dutch Revolt (1566-1609)', in Bert De Munck and Anne Winter (eds.), Gated Communities? Regulating Migration in Early Modern Cities (Farnham 2012) 61-80.

Junot, Yves, 'Les milices bourgeoises au temps des guerres civiles. Force de déstabilisation ou instrument de pacification de la société urbaine? (Valenciennes, anciens Pays-Bas espagnols, 1560-1600)', in Ruiz Ibáñez, José Javier and Serge Brunet (eds.), Les milices dans la première modernité (Rennes 2015) 35-46.

Junot, Yves, 'Pratiques et limites de la réconciliation après les guerres de religion dans les villes des Pays-Bas méridoniaux (années 1570-années 1590)', Revue du Nord 395 (2012/2) 327-346.

Karant-Nunn, Susan, The Reformation of Feeling (Oxford 2010).

Karant-Nunn, Susan, The Reformation of Ritual. An Interpretation of Early Modern Germany (Abingdon 1997).

Koslofsky, Craig, The Reformation of the Dead. Death and Ritual in Early Modern Germany, 1450-1700 (New York 2000).

Laqueur, Thomas, The Work of the Dead. A Cultural History of Mortal Remains (Princeton 2015).

Lahtinen, Anu, and Mia Korpiola, Dying Prepared in Medieval and Early Modern Northern Europe (Leiden 2018).

Lestringant, Frank, Le Théâtre des Cruautés de Richard Verstegan (1578) (Paris 1995).

Loart, Gaspar, La consolation des affligez. Traitant des remèdes et fruits en toutes adversitez (Douai: Baltazar Bellere, 1594).

Lottin, Alain, La révolte des Gueux en Flandre, Artois et Hainaut. Politique, religion et société au Xvie siècle (Lille 2016).

Lottin, Alain, 'Le bannissement des protestants de Lille après la paix d'Arras (1579-1582)', Revue du Nord 66 (1984) 481-498.

Lottin, Alain, Lille, citadelle de la Contre-Réforme? (1598-1668) (Villeneuve d’Ascq 2013). 
Lucassen, Leo, and Boudien De Vries, 'The Rise and Fall of a West-European Textile-Worker Migration System. Leiden, 1586-1700', in Gérard Gayot and Philippe Minard (eds.), Les ouvriers qualifiés de l'industrie (Xvie-Xxe siècle). Formation, Emploi, Migrations (Lille 2001) 23-42.

Luth, Jan, 'Het Geneefse Psalter', in Karla Apperloo-Boersma and Herman Selderhuis (eds.), Calvijn en de Nederlanden (Apeldoorn 2009) 182-193.

Maillard-Luypaert, Monique, 'Pour le salut de mon âme et 'honneur de mon église. Le testament de Grégoire Nicole, chanoine et official de Cambrai (1466,1469)', Revue du Nord 384 (2010/1) 7-51.

Manteau, Mahieu, and Pierre-Ignace Chavatte, Chronique de Mahieu Manteau et de Pierre-Ignace Chavatte. Debièvre, Eugène (ed.) (Lille 1911).

Marnef, Guido, Antwerpen in de tijd van de Reformatie. Ondergronds protestantisme in een handelsmetropool 1550-1577 (Antwerpen 1996).

Marnef, Guido, 'De Nederlandse Geloofsbelijdenis in context. De Confession de Foy en het vroege gereformeerd protestantisme in de Nederlanden', Theologia Reformata 55 (2012) 237-251.

Marnef, Guido, 'The Dynamics of Reformed Militancy. The Netherlands, 1566-1585', in Philip Benedict, Guido Marnef, Henk van Nierop, and Marc Venard (eds.), Reformation, Revolt and Civil War in France and the Netherlands 1555-1585 (Amsterdam 1999) 51-68.

McDonald, Grantley, 'Burned to Dust. Censorship and Repression of Theological Literature in the Habsburg Netherlands during the 1520s', in Violet Soen, Dries Vanysacker, and Wim François (eds.), Church, Censorship and Reform in the Early Modern Habsburg Netherlands (Turnhout 2017) 25-49.

Milner, Matthew, 'The Senses in Religion. Towards the Reformation of the Senses', in Herman Roodenburg (ed.), A Cultural History of the Senses in the Renaissance (London 2014) 87-105.

Moreau, Gérard, 'Catalogue des livres brûlés à Tournai par ordre du duc d'Albe (16 juin 1569)', in Horae Tornacenses. Recueil d'études d'histoire publiées à l'occasion du viIIe centenaire de la consécration de la cathédrale de Tournai (Tournai 1971) 194-213.

Moreau, Gérard, Histoire du Protestantisme à Tournai jusqu'à la veille de la Révolution des Pays-Bas (Paris 1962).

Moreau, Gérard, 'Les Synodes des Eglises Wallonnes des Pays-Bas en 1563', Nederlands Archief voor Kerkgeschiedenis 47 (1965/1) 1-11.

Morgan, David, 'Introduction', in David Morgan (ed.), Religion and Material Culture. The Matter of Belief (London 2010).

Morsa, Denis, 'Lurbanisation de la Belgique (1500-1800). Taille, hiérarchie et dynamique des villes', in Philippe Guignet (ed.), Démographie urbaine, urbanisation, urbanisme dans la région du Nord et en Belgique (du xve siècle à nos jours) (Villeneuve-d’Ascq 1997) 303-330.

Mudde, Caroline, Rouwen in de marge. De materiële rouwcultuur van de katholieke geloofsgemeenschap in vroegmodern Nederland. PhD diss., Universiteit Utrecht, 2018.

Murphy, Emilie, 'Musical self-fashioning and the 'theatre of death' in late Elizabethan and Jacobean England', Renaissance Studies 30 (2016/3) 410-429.

Nicholls, David, 'The Theatre of Martyrdom in the French Reformation', Past and Present 121 (1988) 49-73.

Paillard, Charles, Une page de l'histoire religieuse des Pays-Bas. Le procès de Pierre Brully, successeur de Calvin comme ministre de l'Eglise française réformée de Strasbourg, sentences prononcées contre Brully et contre ses adhérents, Tournay, 1544-1545, d’après les papiers inédits des archives du Royaume de Belgique (Brussels 1878).

Payen, Pontus, Mémoires de Pontus Payen. Alexandre Henne (ed.) (Brussels 1860).

Pollmann, Judith, 'Burying the dead, reliving the past. Ritual, resentment and sacred space in the Dutch Republic', in Benjamin Kaplan (ed.), Catholic Communities in Protestant States. Britain and the Netherlands (1570-1720) (Manchester 2008) 84-102.

Resch, Claudia, 'Reforming Late Medieval ars moriendi. Changes and Compromises in Early Reformation Manuals for Use at the Deathbed', in Tarald Rasmussen and Jon Flaeten (eds.), Preparing for Death, Remembering the Dead (Göttingen 2015) 153-172.

Reinis, Austra, Reforming the Art of Dying. The ars moriendi in the German Reformation (1519-1528) (Ashgate 2006). 
Roberts, Penny, 'Contesting sacred space. Burial disputes in sixteenth-century France', in Bruce Gordon and Peter Marshall (eds.), The Place of the Dead. Death and Remembrance in Late Medieval and Early Modern Europe (New York, 2000) 131-148.

Rolland, Paul, Histoire de Tournai (Tournai 1956).

Roodenburg, Herman (ed.), A Cultural History of the Senses in the Renaissance (London, 2014).

Selderhuis, Herman, 'Ars moriendi in early modern Calvinism', in Tarald Rasmussen and Jon Flaeten (eds.), Preparing for Death, Remembering the Dead (Göttingen 2015) 109-122.

Soen, Violet, and Laura Hollevoet, 'Le Borromée des anciens Pays-Bas? Maximilien de Berghes, archevêque de Cambrai et l'application du Concile de Trente (1564-1567)', Revue du Nord 419 (2017/1) 41-65.

Soetaert, Alexander, De katholieke drukpers in de kerkprovincie Kamerijk. Contacten, mobiliteit en transfers (1559-1659) (Leuven 2019).

Spicer, Andrew, 'After Iconoclasm. Resacralisation in the Southern Netherlands, ca. 1566-1585', Sixteenth Century Journal 44 (2013/2) 411-433.

Spicer, Andrew, 'Rest of their bones. Fear of death and Reformed burial practices', in William Naphy and Penny Roberts (eds.), Fear in early modern society (Manchester 1997) 167-183.

Spinks, Jennifer, and Charles Zika (eds.), Disaster, Death and the Emotions in the Shadow of the Apocalypse, 1400-1700 (Basingstoke 2016).

Suykerbuyk, Ruben, 'De sacra militia contra iconomachos. Civic Strategies to Counter Iconoclasm in the Low Countries (1566)', BMGN/Low Countries Historical Review 131 (2016/1) 15-35.

Tucker, Jameson, The Construction of Reformed Identity in Jean Crespin's Livre des Martyrs (Abingdon 2017).

Turchetti, Mario, Tyrannie et tyrannicide de l'Antiquité à nos jours (Paris 2001).

Van Bruaene, Anne-Laure, Koenraad Jonckheere, and Ruben Suykerbuyk (eds.), 'Beeldenstorm. Iconoclasm in the Sixteenth-Century Low Countries', special issue of BMGN/Low Countries Historical Review $(2016 / 1)$.

Verriest, Léo, 'La perte des archives du Hainaut et de Tournai', Revue belge de philologie et d'histoire 21 (1942) 186-193.

Viret, Pierre, L'office des mortz, fait par dialogues, en maniere de devis (Geneva: Jean Gerard, 1552).

Viret, Pierre, Traittez divers pour l'instruction des fideles qui resident et conversent es lieux et pais esquels il ne leur est permis de vivre en la pureté et liberté de l'Evangile (Geneva: Jean Rivery, 1559).

Warny de Wisenpière, Philippe, Mémoires sur le siège de Tournay. Alexandre-Guillaume Chotin (ed.) (Brussels 1860).

Willens-Closset, Marie-Paule, 'Le protestantisme à Lille jusqu’à la veille de la révolution des Pays-Bas (1521-1565)', Revue du Nord 52 (1970) 199-216.

Woo, Kenneth, 'The House of God in Exile. Reassessing John Calvin's Approach to Nicodemism in Quatre Sermons (1552), Church History and Religious Culture 95 (2015/2-3) 222-244.

Woolgar, Chris, 'What makes things holy? The senses and material culture in the later Middle Ages', in Robin MacDonald, Emilie Murphy, and Elizabeth Swann (eds.), Sensing the Sacred in Medieval and Early Modern Culture (Abingdon 2018) 60-78. 